\title{
PEMBATASAN PERKEMBANGAN PERMUKIMAN KAWASAN PINGGIRAN SEBAGAI UPAYA PENGENDALIAN PERKEMBANGAN KOTA SEMARANG
}

\author{
Limitataions on the Development of The Suburbs Area as The Control \\ Efforts of Semarang City Development
}

\section{Bitta Pigawati ${ }^{1,}$ Nany Yuliastuti2 ${ }^{2}$ and Fadjar Hari Mardiansjah ${ }^{3}$}

\begin{abstract}
Abstrak:. Kebutuhan untuk bermukim merupakan kebutuhan dasar masyarakat yang harus terpenuhi. Lemahnya penegakan hukum dan penyadaran masyarakat terhadap aspek penataan ruang berimplikasi munculnya kawasan permukiman di berbagai lokasi yang kurang sesuai bagi peruntukannya. Permukiman di Kota Semarang berkembang sangat cepat dan cenderung tidak terarah. Pertambahan luas kawasan terbangun khususnya kawasan permukiman mengindikasikan berkurangnya lahan terbuka hijau dan kawasan resapan. Fenomena ini mulai terlihat dibagian pinggir Kota Semarang. Penelitian ini bertujuan mengkaji perkembangan permukiman di wilayah bagian pinggir kota sebagai upaya pembatasan perkembangan Kota Semarang. Mencakup 10 wilayah kecamatan, selama kurun waktu 10 tahun. Menggunakan metode deskriptif kuantitatif dan analisis spasial. Hasil penelitian menunjukan bahwa kelengkapan sarana merupakan faktor yang paling berpengaruh terhadap perkembangan permukiman. Permukiman cenderung berkembang teratur dengan pola yang seragam. Perkembangan kawasan permukiman juga terjadi pada kawasan resapan dan di lokasi yang tidak sesuai bagi peruntukannya sehingga perlu dilakukan upaya pembatasan perkembangan permukiman. Masih tersedia beberapa lokasi yang memungkinkan untuk pembangunan permukiman di Kawasan Pinggiran Kota Semarang. Pemerintah perlu menindaklanjuti dengan pemberian informasi kepada masyarakat sehingga perkembangan permukiman sesuai dengan arahan perkembangan kota
\end{abstract}

\section{Kata Kunci: Perkembangan Permukiman, Kawasan Pinggiran, Pusat Kota, Perkembangan Kota}

\begin{abstract}
The need to settle is a basic need of people that must be fulfilled. The weakness of law enforcement and public awareness on the spatial planning implicate the emergence of settlement areas in various locations that are less suitable for its allocation. The settlements in Semarang are growing very fast and tending to be unfocused. The increase of built area especially in residential areas indicates reduced of green open space and the catchment area. This phenomenon begins to appear in the outskirts of Semarang. This study aims to examine the development of settlements in suburbs area as an effort to limit the development of Semarang. It includes 10 districts, over 10 years. This study used descriptive quantitative and spatial analysis. The results showed that the completeness of the factor is the most influential factor on the development of settlements. Settlements tend to develop regularly with a regular pattern. The residential development areas also occur in the catchment area and in locations that are not suitable for allotment, so that limitation efforts should be made on the development of settlements. There are still some locations that are possible for the construction of settlements in the outskirts of Semarang. The government needs to follow up this issue by providing information to the community, so that the development of settlement is in accordance with the direction of urban development
\end{abstract}

Keywords: Development of Settlements, Suburbs, City Center, City Development

\footnotetext{
${ }^{1}$ Departemen Perencanaan Wilayah dan Kota, Fakultas Teknik, Universitas Diponegoro
} 


\section{PENDAHULUAN}

Pertumbuhann dan Perkembangan kota pada prinsipnya menggambarkan proses berkembangnya suatu kota Peran kota sebagai pusat aktivitas utama ekonomi dewasa ini, menjadi daya tarik mengapa pertumbuhan kota perlu diperhatikan (Soyinka \& Siu, 2017; Jat, Choudhary, \& Saxena, 2017; Ma \& Xu, 2010). Faktor utama perkembangan kota adalah pertumbuhan penduduk dan konsumsi lahan per kapita (Bagheri \& Tousi, 2017). Aktivitas penduduk dan konversi lahan menyebabkan perubahan pada struktur ruang kota, dengan munculnya permukiman baru di kawasan pinggirian (H. Cheng, Liu, He, \& Shaw, 2017). Secara fisik, perkembangan suatu kota dapat dicirikan dari penduduknya yang makin bertambah dan makin padat, bangunan-bangunannya yang semakin rapat dan wilayah terbangun terutama permukiman yang cenderung semakin luas, serta semakin lengkapnya fasilitas kota yang mendukung kegiatan sosial dan ekonomi kota (Branch, 1995). Perkembangan Kota Semarang menjadi kota Metropolitan menimbulkan berbagai dampak baik positif maupun negatif. Secara fisik perkembangan kota ini terlihat di dua lokasi yang mencirikan arah perkembangan yang berbeda, yaitu pada kawasan pinggiran kota dan di kawasan pusat kota. Wilayah Semarang mengalami perluasan kota secara fisik ke arah horizontal yang terjadi di kawasan pinggiran kota dan perkembangan ke arah vertilkal di kawasan pusat kota. Perkembangan Kota Semarang menyebabkan lahan terbangun di Kota Semarang cenderung meningkat. Sebaliknya ruang terbuka hijau semakin menurun. Pertumbuhan kawasan perkotaan memiliki dampak yang signifikan terhadap degradasi lingkungan (Widodo et al., 2015)

Peran kota ditentukan oleh karakteristik fungsi kota yang diembannya, dan tergantung pada ketersediaan aksesibilitas untuk mencapai wilayah pinggirannya (Rodinelli, D. A., \& Ruddle, 1978). Perkembangan Kota metropolitan saat ini ditandai dengan ciri desentralisasi kawasan permukiman dan lapangan kerja (Glaeser, Edward, Matthew, \& Kahn, 2003) Perkembangan kota yang tidak memusat cenderung membutuhkan infrastruktur yang lebih banyak dan alokasi dana juga lebih besar (Solé-Ollé, Albert, \& Rico, 2010). Hal ini wajar karena penduduk di pinggiran kota juga menuntut adanya penyediaan sarana dan prasarana yang memadai. Seiring dengan berkembang sistem perkotaan yang terus berlangsung di seluruh dunia, terjadi peningkatan jumlah tipologi kawasan periperi, hal ini merupakan tantangan bagi para perencana kota dalam mewujudkan pembangunan berkelanjutan.(Geneletti, La Rosa, Spyra, \& Cortinovis, 2017). Perencanaan yang berkelanjutan, terkait dengan perencanaan fisik dan tata ruang, yang bertujuan untuk mengoptimalkan distribusi dan alokasi kegiatan, dalam konteks yang terbatas pada ruang atau dalam batas-batas administratif tertentu, memberikan indikasi dan / atau peraturan untuk kegiatan penggunaan lahan dan keterkaitannya (Riddell, 2004).

Kota Semarang saat ini merupakan salah satu kota metropolitan di Indonesia. Sebagai kota metropolitan, Kota Semarang mendapatkan tekanan yang cukup signifikan sehingga berpengaruh terhadap perubahan guna lahan dan peningkatan jumlah penduduk. Kondisi semacam ini dapat dikatakan sebagai kota yang mengalami pemekaran atau ekspansi keruangan (spatial expantion). Seiring dengan perkembangan tersebut, kepadatan penduduk Kota Semarang berkembang kearah pinggiran kota (suburbanisasi), yaitu kearah selatan dan kearah timur Kota Semarang. (Rudiarto, Handayani, \& Pigawati, 2013). Perkembangan Kota Semarang ke daerah pinggiran berlangsung sangat cepat. Kantongkantong permukiman baru tumbuh dengan subur menempati ruang-ruang terbuka menjadi lahan terbangun

Untuk mendapatkan pemahaman tentang perkembangan kota, ada beberapa sudut pandang yang digunakan untuk mendefinisikan kota. Kota diartikan sebagai suatu sistem jaringan kehidupan manusia yang ditandai dengan kepadatan penduduk yang tinggi dan strata sosial ekonomi yang heterogen dengan corak materialistis (Bintarto, 1979). Kota 
merupakan suatu pemukiman yang relatif besar, padat, dan permanen yang dihuni oleh orang-orang yang heterogen kedudukan sosialnya. Struktur mata pencaharian penduduk kota sebagian besar non agraris (Daldjoeni, 1987). Kota memiliki populasi yang besar, dan cenderung meningkat pesat dari waktu ke waktu. (Jat et al., 2017 ; Brueckner \& Helsley, 2011), sedangkan Pusat Kota adalah Inti dari suatu kota yang pada awalnya merupakan permukiman, yang kemudian berkembang menjadi pusat perkantoran, komersial dan pusat komunikasi yang disebut Central Business District/CBD (Bourne, 1982). Kota berfungsi sebagai wadah segala aktivitas masyarakat/ warga kota. Segala aktifitas tersebut mempengaruhi bentuk suatu kota. Bentuk kota merupakan hasil suatu proses budaya manusia, dalam menciptakan ruang dan kehidupannya pada kondisi geografis tertentu (Kostof, 1991).

Permukiman adalah bagian dari lingkungan hunian yang terdiri atas lebih dari satu satuan perumahan yang mempunyai prasarana, sarana, utilitas umum, serta mempunyai penunjang kegiatan fungsi lain di kawasan perkotaan atau kawasan perdesaan (Keputusan Menteri Permukiman dan Prasarana Wilayah No. 534/KPTS/M/2001 tentang Standar Pelayanan Minimal untuk Permukiman). Permukiman merupakan kawasan yang didominasi oleh lingkungan hunian dengan fungsi utama sebagai tempat tinggal yang dilengkapi dengan prasarana, sarana lingkungan, dan tempat kerja yang memberikan pelayanan dan kesempatan kerja terbatas untuk mendukung perikehidupan dan penghidupan, sehingga fungsi permukiman tersebut dapat berdaya guna dan berhasil guna (Direktorat Jenderal Cipta Karya. \& Ikatan Ahli Perencanaan., 1998). Sarana permukiman adalah fasilitas dalam lingkungan hunian yang berfungsi untuk mendukung penyelenggaraan dan pengembangan kehidupan sosial, budaya, dan ekonomi. (Keputusan Menteri Permukiman dan Prasarana Wilayah No. 534/KPTS/M/2001 tentang Standar Pelayanan Minimal untuk Permukiman).

Doxiadis (1968), mengungkapkan bahwa sistem permukiman terdiri dari susunan berbagai elemen yaitu Nature (unsur alami) yakni tersedianya sumber-sumber daya alam seperti geologi, topografi, hidrologi, tanah, iklim maupun unsur hayati yaitu vegetasi dan fauna. Kemudian yang kedua elemen Man (manusia) yang mendiami lokasi tersebut dengan segala kebutuhan pribadinya seperti biologis, emosional, nilai-nilai moral, sosial dan lainlain. Ketiga adalah Society (masyarakat) yakni adanya manusia sebagai mahkluk sosial yang mempunyai keinginan dasar untuk menjalankan kehidupannya bersama dengan orang lain. Keempat adalah Shells (ruang) dimana manusia sebagai individu maupun kelompok melangsungkan kegiatan kehidupannya. Dan kelima adalah Network (jaringan) yang merupakan sistem baik alami maupun buatan manusia yang menunjang aktifitas kegiatan manusia seperti tersedianya jalur trasnportasi, air bersih, energi listrik dan lain sebagainya. Kelima elemen ini merupakan penyusun suatu permukiman yang masing-masing akan memberikan ciri tersendiri sesuai karakter penyusunnya.

Perubahan guna lahan mampu menjadi pemicu awal munculnya gejala disintegrasi sosio-spasial permukiman karena guna lahan merupakan variabel fundamental yang dampak dan perubahannya mampu mempengaruhi kehidupan manusia dan lingkungan secara fisik (Ali, 2012). Ekspansi kota yang cepat dan tidak teratur, didorong oleh pertumbuhan ekonomi berkecepatan tinggi telah dikritik sebagai penyebab utama kehilangan lahan hijau, ketidak setaraan sosial, dan kerusakan lingkungan di kota-kota di China (J. \& I. M. Cheng, 2003 ; Yeh, 1999; Ding, 2009; etc. Wang, Krstikj, \& Koura (2017). Faktor pendorong utama perubahan penggunaan lahan perkotaan adalah tingkat pertumbuhan penduduk dan penduduk migran (de la Luz Hernández-Flores et al., 2017) Perkembangan ekonomi dan pertumbuhan penduduk telah memicu perubahan penggunaan laahan akibat urbanisasi dan industrialisasi (Jat et al., 2017). Pemisahan yang terjadi pada permukiman menjadi bagianbagian kecil mengelompok sesuai dengan tingkat ekonomi dan akses terhadap lahan. Pengelompokan permukiman pada umumnya disebabkan oleh beberapa penyebab yaitu seperti kelas sosial dan kemampuan akses lahan untuk membangun hunian tempat tinggal. 
Preferensi masyarakat memilih permukiman mempertimbangkan karakteristik lingkungan seperti lokasi pendidikan, kriminalitas, kualitas lingkungan, fasilitas, komposisi sosio demografi, karakteristik permukiman dan harga lahan (Wulangsari, 2014). Faktor yang berpengaruh terhadap perkembangan permukiman antara lain faktor fisik alamiah, faktor social, (Sumaatmadja, 1989). Menurut Yang, Xu, \& Long (2016) faktor-faktor yang mempengaruhi perbedaan distribusi spasial permukiman adalah faktor geografi (ketinggian, curah hujan), jarak ke jalan utama, jarak ke pusat kota, infrastruktur/investasi fisik dan faktor ekonomi.

Pemilihan lokasi permukiman sebagai tempat tinggal dipengaruhi beberapa faktor tergantung pada aktifitas kota yang bersangkutan. Menurut Budihardjo (1991), faktor-faktor pemilihan lokasi permukiman yaitu aksesibilitas, ketersediaan ruang dan lahan, ketersediaan sarana dan prasarana permukiman, fisik dasar dan kondisi lingkungan. Status sosial merupakan salah satu faktor yang yang menjadi pendorong terjadinya pengelompokan permukiman. Masyarakat dengan pendapatan tinggi dan status sosial yang tinggi lebih memiliki kesempatan memilih lingkungan permukiman sesuai dengan minat dan selera mereka sedangkan masyarakat yang pendapatan rendah mempunyai keterbatasan untuk memilih lingkungan permukiman mereka (Pacione, 2005).

Daerah pinggiran kota adalah suatu daerah yang juga dikenal sebagai daerah "urban fringe" atau daerah "peri urban" merupakan daerah yang memerlukan perhatian yang serius karena mempunyai peran penting terhadap kehidupan penduduk baik desa maupun kota di masa yang akan datang (Yunus, 2008). Perkembangan fisik kota berdasarkan teori tentang lahan kota (Chapin \& Keiser, 1979) dapat diidentifikasi berdasarkan bertambah luasnya kawasan terbangun yang sebagian besar dimanfaatkan sebagai kawasan permukiman. Faktor-faktor kenampakan keruangan pinggiran kota sebagai bentuk perkembangan permukiman pinggiran kota secara fisik yang paling mempengaruhi tipologi perkembangan kelompok permukiman yaitu: faktor pertumbuhan penduduk (population growth), faktor hakhak kepemilikan lahan (property rights), dan faktor persaingan memperoleh lahan (competition for land). (Warsono, Soetomo, \& Wahyono, 2012). Daerah pinggiran perkotaan ditandai oleh kerberagaman lanskap, termasuk kawasan perumahan berpagar, rumah pedesaan yang tersebar, dan kawasan industry yang kegiatannya bersebelahan dengan aktivitas komersial, kawasan residensial hingga lahan pertanian (Tian, Liang, \& Zhang, 2017; Leaf, 2002).

Pola permukiman merupakan cerminan penyesuaian penduduk terhadap lingkungan alam seperti topografi, iklim, dan tanah. Tingkat penyesuaian tersebut sangat tergantung pada faktor sosial ekonomi dan kultur penduduknya. Terbentuknya pola tempat kediaman penduduk akan dipengaruhi oleh keadaan lingkungan alam, keadaan sosial ekonomi, serta keadaan budaya (Pacione, 1984). Pola permukiman memberikan kesan tentang persebaran fisik permukiman beserta kepadatan penghuninya (Zee, 1979). Pola permukiman membahas sifat dari persebaran permukiman yang secara umum merupakan hubungan antara faktorfaktor yang menentukan terjadinya sifat persebaran. Salah satu cara mengukur pola permukiman dapat dilakukan dengan menggunakan model dan analisis tetangga terdekat/nearest neighborhood analysis, yaitu dengan menghitung besarnya parameter tetangga terdekat $(\mathrm{T})$

Kebijakan arahan pemanfaatan lahan permukiman Kota Semarang secara eksplisit telah dikemukakan dalam Rencana Tata Ruang Kota Semarang dengan menetapkan lokasi dan sebarannya berdasarkan daya dukung lingkungannya. Pelaksanaan penataan ruang adalah upaya pencapaian tujuan penataan ruang melalui pelaksanaan perencanaan tata ruang, pemanfaatan ruang, dan pengendalian pemanfaatan ruang (Undang- Undang No 26 Tahun 2007 tentang Penataan Ruang). Kesesuaian antara arahan pemanfaatan ruang dan kondisi perkembangan dilapangan menjadi kunci utama untuk melihat sejauh mana kebijakan tataruang dapat mengakomodasi perkembangan masing masing kawasan dan 
penyimpangannya, sehingga dapat digunakan sebagai acuan evaluasi terhadap kondisi eksisting.

Pembatasan perkembangan permukiman perlu dilakukan sebagai upaya pengendalian perkembangan Kota. Kecenderungan pertambahan luas kawasan terbangun terjadi dalam waktu yang relatif cepat, terutama yang digunakan sebagai kawasan permukiman. Dikatakan oleh Spencer (1979) bahwa, proses perkembangan kota ke arah pinggiran yang cenderung alamiah, daripada terencana, merupakan suatu gejala suburbanisasi premature dan tidak terencana, sehingga menciptakan perluasan kota yang liar dan tidak teratur, serta tidak terkendali. Kondisi masa depan pembangunan dan permukiman di Indonesia harus diarahkan kepada pola pembangunan berkelanjutan. Hal ini penting guna keberlangsungan pembangunan dan dampaknya terhadap kondisi lingkungan. Kegiatan penataan ruang berkaitan juga dengan perencanaan pembangunan sehingga dokumen yang dihasilkan dari kegiatan penataan ruang dan perencanaan pembangunan sama-sama ditujukan untuk memprediksi kegiatan yang akan dilakukan di masa mendatang (Oetomo, 1998).

Penginderaan Jauh dan Sistem Informasi Geografis dapat digunakan untuk memetakan dan menganalisis perkembangan kota serta mendeteksi perubahan penutupan lahan. Pengertian Penginderaan Jauh (Weng, 2010): Remote sensing refers to the activities of recording, observing, and perceiving (sensing) objects or events in far-away (remote) places. In remote sensing, the sensors are not in direct contact with the objects or events being observed. Melalui proses analisis citra penginderaan jauh, dapat dilakukan estimasi yang lebih baik tentang perkembangan wilayah dan kota. (Pigawati,B dan Iwan Rudiarto, 2011)melakukan penelitian Kawasan Permukiman di Kota Semarang, menilai kemampuan citra yang dihasilkan oleh teknologi Penginderaan Jauh untuk melakukan kajian perkembangan kawasan permukiman di Kota Semarang. Citra dapat digunakan untuk monitoring perkembangan kawasan permukiman dan perkotaan yang relative pesat perkembangannya. Perkembangan Kawasan Pinggiran Kota Semarang secara spasial dapat digambarkan melalui visualisasi modifikasi Digital Elevation Model.

\section{Lokasi Penelitian}

Wilayah penelitian adalah Kota Semarang bagian pinggir. Mencakup 10 wilayah kecamatan, dengan 120 jumlah kelurahan. Wilayah penelitian ini dapat dikelompokkan menjadi 4 yang dibedakan secara geografis berdasarkan orientasi terhadap pusat Kota Semarang yaitu:

- Lokasi 1 adalah Kawasan pinggiran Kota Semarang sebelah Barat berbatasan dengan Kabupaten Kendal (Kecamatan Ngaliyan, Kecamatan Mijen)

- Lokasi 2 adalah Kawasan pinggiran Kota Semarang sebelah Utara berbatasan dengan laut (Kecamatan Tugu dan Kecamatan Semarang Barat Kecamatan Semarang Utara Kecamatan Genuk)

- Lokasi 3 adalah Kawasan pinggiran Kota Semarang sebelah Timur berbatasan dengan Kab Demak (Kecamatan Pedurungan, Kecamatan Tembalang)

- Lokasi 4 adalah Kawasan pinggiran Kota Semarang sebelah Selatan berbatasan dengan Kabupaten Semarang. (Kecamatan Banyumanik, Kecamatan Gunungpati

\section{BAHAN DAN METODE}

Data yang digunakan dalam penelitian ini berupa data citra satelit Kota Semarang tahun 2006 dan 2016. Peta Tematik, Data BPS dan hasil olah kuisioner, menggunakan pendekatan kuantitatif, dimana semua data dan informasi dikumpulkan, diolah dan dianalisis secara kuantitatif dengan memanfaatkan data indraja dan sistem informasi geografis.

Analisisi yang dilakukan meliputi: 
1. Analisis kondisi permukiman. Analisis ini dilakukan dengan tujuan untuk melihat lingkungan permukiman berdasarkan indikator kependudukan, sosial ekonomi, dan kelengkapan sarana dan prasarana permukiman. Analisis ini akan menghasilkan karakteristik permukiman pada kawasan perkembangan

2. Analisis perkembangan permukiman, analisis ini bertujuan untuk mengetahui pertambahan luas permukiman selama periode waktu 10 tahun (tahun 2006 - 2016). Berdasarkan hasil analisis dapat diketahui luas dan sebaran distribusi keruangan permukiman pada wilayah perkembangan

3. Analisis faktor yang berpengaruh terhadap perkembangan permukiman, bertujuan untuk menjelaskan faktor penyebab perkembangan permukiman di kawasan pinggiran Kota Semarang

4. Arahan pembatasan perkembangan permukiman kawasan pinggiran sebagai upaya mengarahkan perkembangan permukiman berdasarkan kesesuaian lahannya

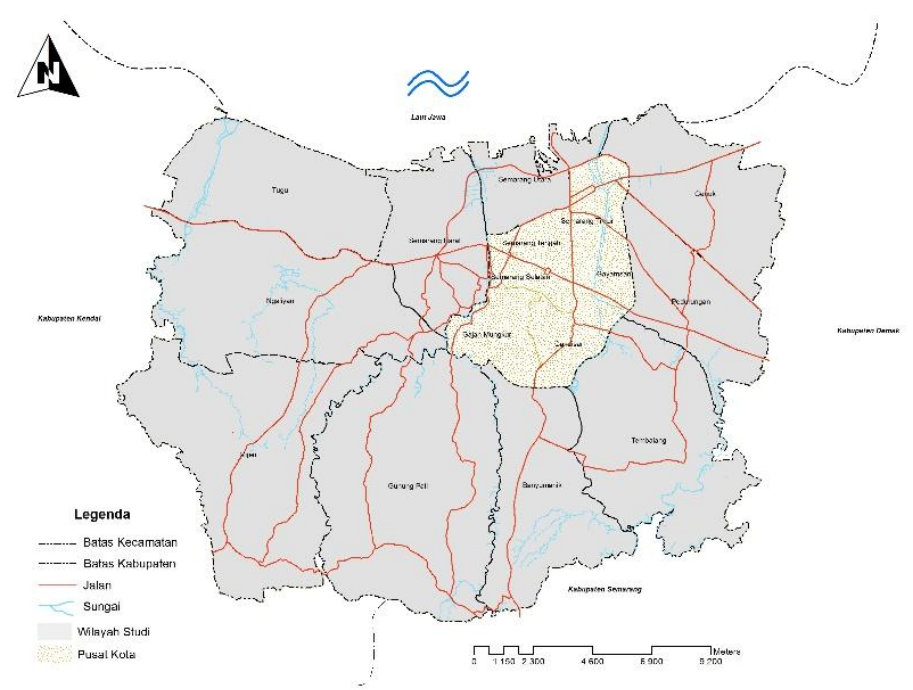

Sumber: Hasil Olahan Peta Dasar

\section{Gambar 1. Peta Lokasi Wialyah Studi}

\section{HASIL DAN PEMBAHASAN}

Jumlah penduduk Kawasan Pinggiran kota Semarang Tahun 2016 sebesar 1.150 .914 jiwa dengan laju pertumbuhan selama 10 tahun sebesar 2\% . Mata Pencaharian penduduk kawasan pinggiran Kota Semarang sebagian besar bekerja sebagai buruh industri $20 \%$ dan 238.755 jiwa berpendidikan $\leq$ tamat Sekolah Dasar (SD). Terjadi peningkatan kualitas sumberdaya manusia terlihat dari data bertambahnya jumlah penduduk yang berpendidikan tamat perguruan tinggi yang meningkat cukup besar (139.7\%). Sarana dan prasarana permukiman di Kawasan Pinggiran Kota Semarang tersedia cukup lengkap dengan kondisi baik. 

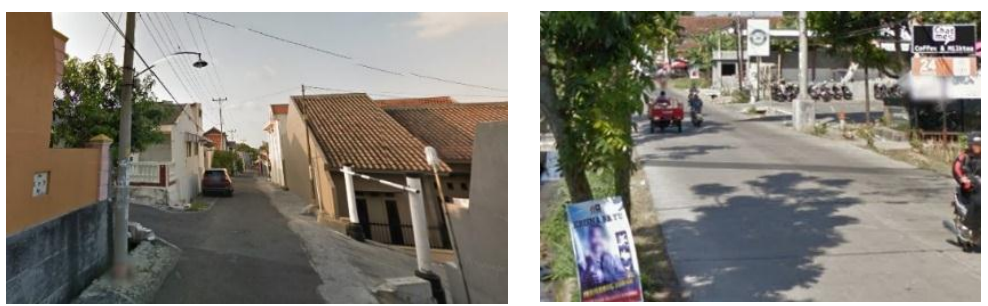

Sumber: Hasil Observasi, 2017

Gambar 2. Kondisi Jalan dan Drainase di Kawasan Pinggiran Kota Semarang

Pola permukiman membahas sifat dari persebaran permukiman yang secara umum merupakan hubungan antara faktor-faktor yang menentukan terjadinya sifat persebaran. Salah satu cara mengukur pola permukiman dapat dilakukan dengan menggunakan model dan analisis tetangga terdekat/ nearest neighborhood analysis (Hagget, 1985). Analisis ini berfungsi untuk mengetahui pola pengelompokan permukiman secara spasial berdasarkan indeks penyebaran tetangga terdekat $(\mathrm{T})$ Menggunakan rumus berikut :

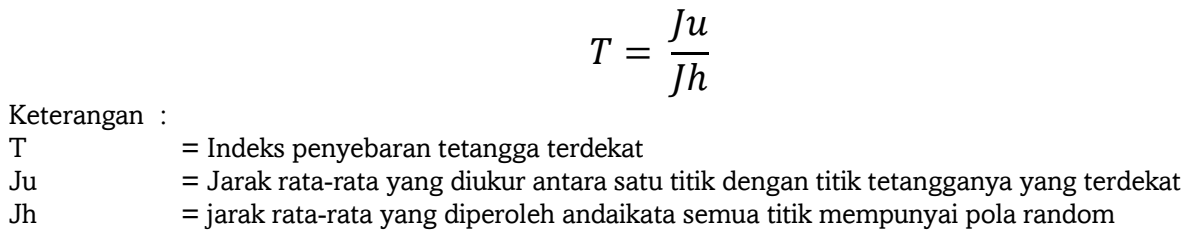

Perhitungan Ju dan Jh dapat diketahui berdasarkan formula berikut;

$$
\begin{gathered}
J u=\frac{\sum \mathrm{J}}{\sum \mathrm{N}} \\
J h=\frac{1}{2 \sqrt{p}} \rightarrow p=\frac{\sum \mathrm{N}}{L}
\end{gathered}
$$

Keterangan

$\sum \mathrm{J}=$ Jumlah jarak antar satu titik dengan titik lain $\sum \mathrm{N}=$ Jumlah titik

$\mathrm{L} \quad \quad=$ Luas wilayah
Pola permukimjan dapat diketahui berdasarkan nilai $\mathrm{T}$ : $\mathrm{T}=0-0,7$ pola bergerombol/mengelompok $\mathrm{T}=0,71-1,4$ pola acak

$\mathrm{T}=1,41-2,15$ pola tersebar merata

Berikut merupakan titik persebaran pusat permukiman yang terdapat di Kawasan Pinggiran Kota Semarang (Gambar 3).

Tabel 1. Pola Permukiman di Kawasan Pinggiran Kota Semarang Tahun 2016

\begin{tabular}{clll}
\hline No. & \multicolumn{1}{c}{ Kecamatan } & T & \multicolumn{1}{c}{ Pola } \\
\hline 1 & Ngaliyan & 1,46 & Seragam \\
2 & Mijen & 1,55 & Seragam \\
3 & Tugu & 1,04 & Acak \\
4 & Semarang Barat & 1,37 & Acak \\
5 & Semarang Utara & 0,26 & Mengelompok \\
6 & Genuk & 1,42 & Seragam \\
7 & Pedurungan & 1,61 & Seragam \\
8 & Tembalang & 1,47 & Seragam \\
9 & Banyumanik & 1,78 & Seragam \\
10 & Gunungpati & 1,09 & Acak \\
\hline
\end{tabular}

Sumber: Hasil Analisis, 2017 


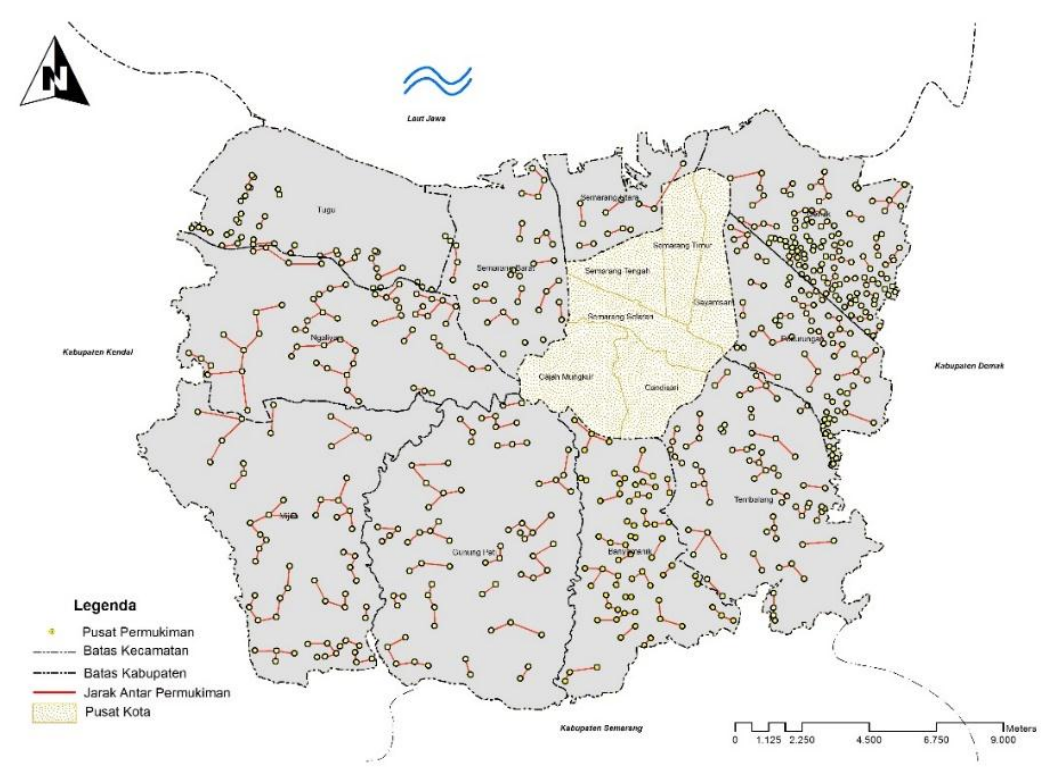

Sumber : Hasil Olahan Peta Dasar

Gambar 3. Pola Permukiman Kawasan Pinggiran Tahun 2016

Sebaran Permukiman dikawasan pinggiran Kota Semarang sebagian besar berpola seragam dengan tataletak bangunan pemukiman relatif teratur. Hal ini dimungkinkan karena pembangunan permukiman sudah terencana dan menyesuaikan dengan jaringan jalan yang telah ada. Keteraturan tataletak bangunan kawasan permukiman di Pinggiran Kota Semarang dapat diidentifikasi secra jelas melalui interpretasi data citra inderaja. Kondisi lingkungan permukiman nampak teratur dengan kualitas lingkungan permukiman baik. Berikut merupakan tabel distribusi permukiman berdasarkan pola keteraturan tataletak bangunan di Kawasan Pinggiran Kota Semarang pada tahun 2016.

Tabel 2. Luas dan Persebaran Permukiman Berdasarkan Tata Letak Bangunan Kawasan Pinggiran 2016

\begin{tabular}{|c|c|c|c|c|c|c|c|}
\hline \multirow{2}{*}{ No } & \multirow{2}{*}{ Kecamatan } & \multicolumn{2}{|c|}{ Permukiman Teratur } & \multicolumn{2}{|c|}{$\begin{array}{c}\text { Permukiman Tidak } \\
\text { Teratur } \\
\end{array}$} & \multicolumn{2}{|c|}{ Non Permukiman } \\
\hline & & $\begin{array}{l}\text { Luas } \\
\text { (ha) }\end{array}$ & $\begin{array}{c}\text { Persentase } \\
(\%)\end{array}$ & $\begin{array}{l}\text { Luas } \\
\text { (ha) }\end{array}$ & $\begin{array}{c}\text { Persentase } \\
(\%)\end{array}$ & $\begin{array}{l}\text { Luas } \\
\text { (ha) }\end{array}$ & $\begin{array}{c}\text { Persentase } \\
(\%) \\
\end{array}$ \\
\hline 1 & Ngaliyan & 306 & 14 & 984 & 11 & 2509 & 12 \\
\hline 2 & Mijen & 110 & 5 & 1047 & 11 & 4598 & 21 \\
\hline 3 & Tugu & 14 & 1 & 438 & 5 & 2726 & 13 \\
\hline 4 & Semarang Barat & 989 & 45 & 302 & 3 & 884 & 4 \\
\hline 5 & Semarang Utara & 0 & 0 & 623 & 7 & 474 & 2 \\
\hline 6 & Genuk & 19 & 1 & 859 & 9 & 1861 & 9 \\
\hline 7 & Pedurungan & 62 & 3 & 1188 & 13 & 822 & 4 \\
\hline 8 & Tembalang & 284 & 13 & 1311 & 14 & 2826 & 13 \\
\hline 9 & Banyumanik & 199 & 9 & 986 & 11 & 1384 & 6 \\
\hline 10 & Gunungpati & 204 & 9 & 1592 & 17 & 3614 & 17 \\
\hline
\end{tabular}

Sumber: Hasil Analisis, 2017 


\section{Perkembangan Permukiman Kawasan Pinggiran Kota Semarang}

Selama kurun waktu 10 tahun (Tahun 2006 - 2016), terjadi perkembangan permukiman di 114 Kelurahan yang tersebar di 10 Kecamatan Kawasan Pinggiran Kota Semarang. Mata pencaharian penduduk di kawasan perkembangan sebagian besar bekerja di sektor industri 25-40 \%. Kondisi ini merupakan indikasi perkembangan Kota Semarang menjadi Kota Industri. Ditemukan hanya di Kecamatan Mijen saja yang penduduknya mayoritas bekerja diluar sektor industri yaitu sektor pertanian. Hal ini dimungkinkan karena masih tersedia lahan terbuka/belum terbangun yang cukup luas. Pekerjaan utama penduduk yang bertempat tinggal pada kawasan perkembangan ini sebagian besar $(42 \%)$ bekerja sebagai buruh (Industri/Tani/Bangunan) dengan pendapatan rata - rata Rp 2.000.000 - Rp 3.500.000/bulan. Tingkat pendidikan penduduk di kawasan perkembangan $49 \%$ berpendidikan $\leq$ SD. Kondisi ini sesuai dengan matapencaharian mereka yang bekerja sebagai buruh.

\begin{tabular}{rlrr}
\multicolumn{2}{c}{ Tabel 3. Perkembangan Permukiman Kawasan Pinggiran Kota Semarang Tahun 2006-2016 } \\
\hline No & \multicolumn{1}{c}{ Kecamatan } & Luas (Ha) & Luas (\%) \\
\hline 1 & Ngaliyan & 383 & 16 \\
2 & Mijen & 247 & 10 \\
3 & Tugu & 140 & 6 \\
4 & Semarang Barat & 329 & 13 \\
5 & Semarang Utara & 21 & 1 \\
6 & Genuk & 414 & 17 \\
7 & Pedurungan & 284 & 12 \\
8 & Tembalang & 157 & 6 \\
9 & Banyumanik & 270 & 11 \\
10 & Gunung Pati & 220 & 9 \\
\hline & & 2465 & 100 \\
\hline
\end{tabular}

Sumber: Hasil Analisis, 2017
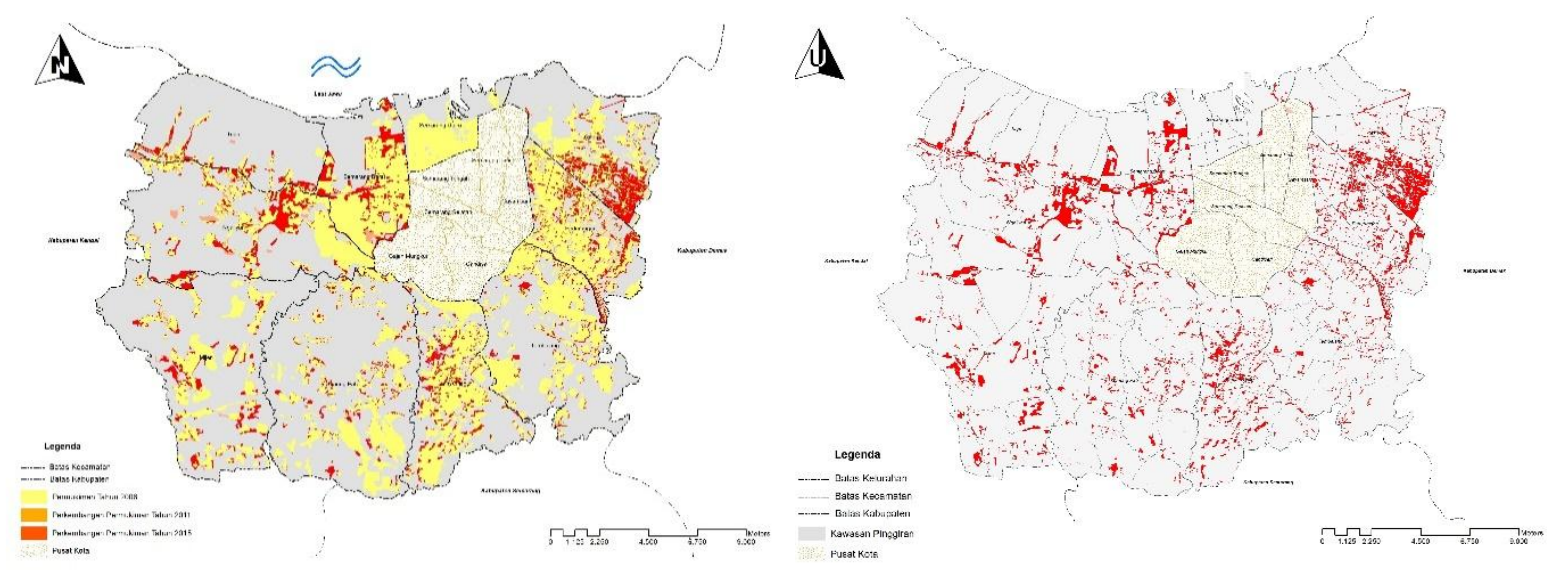

Sumber : Hasil Olahan Peta Dasar, 2016

Gambar 3. Perkembangan Permukiman Kawasan Pinggiran Kota Semarang Tahun 2006-2016

Berikut adalah gambar visualisasi perkembangan permukiman di Kawasan Pinggiran Kota Semarang yang disampaikan dalam bentuk kontur dan Digital Elevation Model yang dimodifikasi. Elevasi menunjukkan luas perkembangan permukiman. 

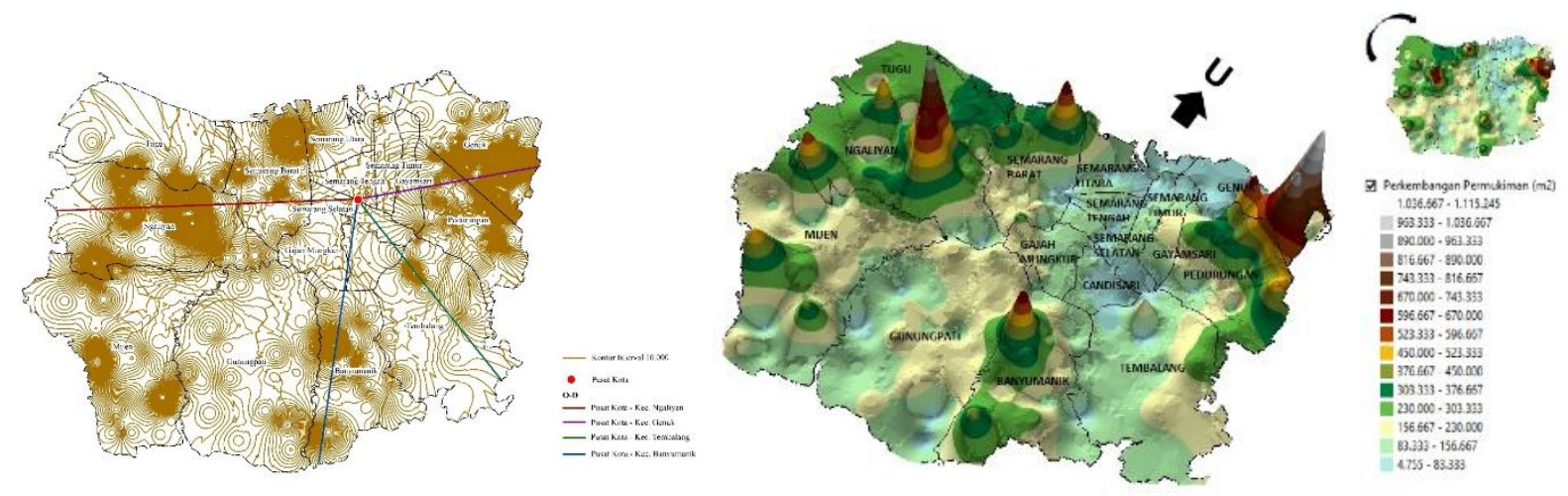

Sumber : Hasil Olahan Peta Dasar, 2016

Gambar 4. Model Perkembangan Permukiman Tahun 2016

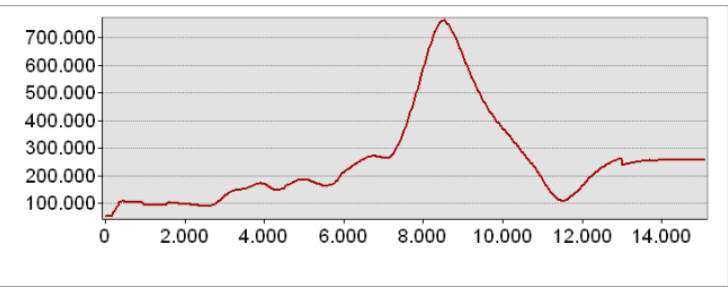

Pusat Kota - Kecamatan Ngaliyan

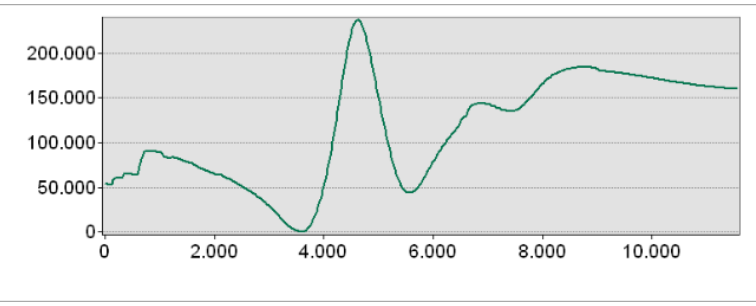

Pusat Kota - Kecamatan Tembalang

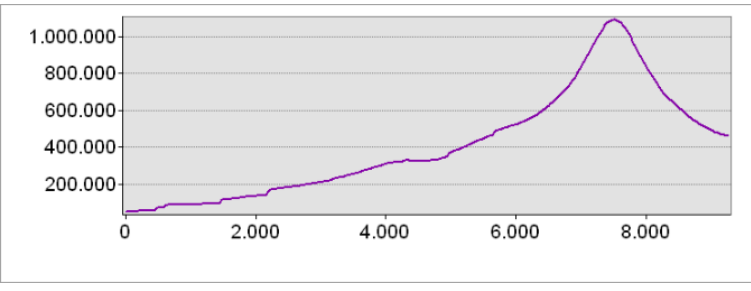

Pusat Kota - Kecamatan Genuk

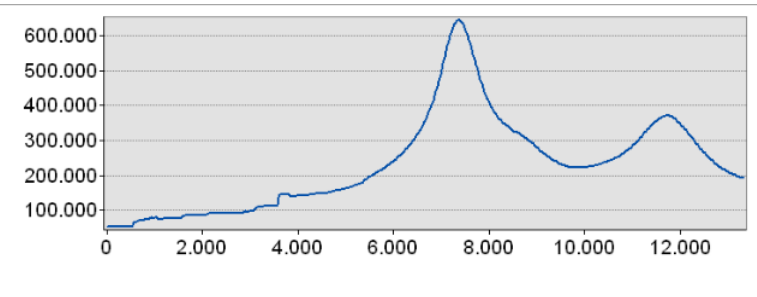

Pusat Kota - Kecamatan Banyumanik

Sumber : Hasil Analisis, 2016

\section{Gambar 5. Profil Perkembangan Permukiman Jarak Pusat Kota - Kawasan Pinggiran Kota}

\section{Faktor Perkembangan Permukiman di Kawasan Pinggiran Kota Semarang}

Wilayah yang teridentifikasi sebagai kawasan perkembangan permukiman terdapat di 114 Kelurahan. Kawasan yang mempunyai luas perkembangan tinggi diketahui terdapat pada lokasi yang dekat dengan jalan utama. Kondisi ini sesuai dengan pendapat yang dikemukankan oleh Yang, Xu, \& Long (2016) namun perkembangan permukiman yang terjadi di wilayah sudi ternyata tidak ada hubungannya dengan jarak dari pusat kota. ( gambar 5). Pertambahan jarak dari pusat kota menuju kawasan pinggiran tidak menunujukkan adanya keterkaitan dengan pertambahan luas perkembangan permukiman. Kondisi ini terjadi karena fasilitas kota sudah tersedia dan tersebar merata di seluruh Kota Semarang.

(Golledge, R. G., \& Stimson, 1987) menyebutkan faktor-faktor yang mempengaruhi perkembangan permukiman antara lain faktor kemudahan aksesibilitas ke pusat-pusat sarana permukiman, faktor bentuk karakteristik fisik dari lingkungan permukiman, faktor 
ketersediaan fasilitas dan pelayanan permukiman, faktor lingkungan sosial, demografi, serta faktor karakter dari lokasi dan tipikal permukiman. Kelengkapan sarana merupakan faktor yang mempengaruhi perkembangan permukiman. Ada keterkaitan antara luas perkembangan permukiman dengan kelengkapan sarana permukiman. Semakin lengkap sarana semakin tinggi tingkat perkembangan kawasan permukimannya.

Faktor lain yang berpengaruh terhadap luas dan arah perkembangan permukimman adalah kondisi fisik kawasan, terutama yang berkaitan dengan keberadaan kawasan rawan bencana banjir dan gerakan tanah. Kawasan rawan bencana merupakan faktor yang dipertimbangkan oleh masyarakat dalam memilih lokasi permukiman karena dapat menimbulkan kerusakan infrastruktur baik ringan maupun berat, robohnya permukiman penduduk, bahkan dapat menimbulkan korban jiwa. Sehingga dianggap kurang aman untuk didirikan sebuah bangunan permukiman.

Pada kawasan perkembangan permukiman ditemukan adanya lokasi yang berada di kawasan rawan bencana banjir $(21,8 \%)$ tersebar di lokasi penelitian. Paling besar terdapat di Kecamatan Genuk dan Kecamatan Semarang Barat, bagian utara Kota Semarang karena berbatasan dengan laut. Wilayah perkembangan permukiman yang berada di kawasan rawan bencana gerakan tanah (5\%) terdapat di beberapa kelurahan, dengan luasan terbesar berada di Kecamatan Gunung Pati dan Kecamatan Mijen. Lokasi dengan gerakan tanah potensi tinggi di kawasan perkembangan seluas 119.2785 Ha (5\%). Sebagian besar terdapat di Kecamatan Ngaliyan, Kecamatan Mijen, Kecamatan Gunungpati dan Kecamatan Banyumanik. Keberadaan kawasan rawan bencana ini mempengaruhi tingkat perkembangan permukiman, luas perkembangan permukiman di lokasi gerakan tanah tinggi relatif kecil, sedangkan perkembangan permukiman di lokasi kawasan gerakan tanah dengan potensi menengah tidak menjadi kendala untuk dipilih sebagain permukimkan. Lokasi kawasan perkembangan permukiman 43 \% luasnya ternyata berada di kawasan resapan/ konservasi, sebagian besar ditemukan di Kecamatan Gunung Pati dan Kecamatan Mijen.

\section{Pembatasan Perkembangan Permukiman di Kawasan Pinggiran Kota Semarang}

Hasil penelitian menunjukkan bahwa perkembangan permukiman terjadi di beberapa lokasi yang kurang sesuai, karena berada di kawasan rawan bencana dan/atau tidak sesuai bagi peruntukannya. Pembatasan perkembangan permukiman dilakukan bertujuan untuk mengarahkan perkembangan kota supaya sesuai dengan arahan rencana tata ruang kota serta melindungi penduduk dari bencana dikarenakan bertempat tinggal pada lokasi kawasan rawan bencana yang tidak layak serta kurang aman untuk dijadikan sebagai lokasi permukiman. Upaya pembatasan perkembangan permukiman dapat dilakukan dengan penertiban pendirian bangunan, sesuai dengan ijin pendiriannya serta pemberian informasi kepada masyarakat tentang keberadaan lokasi yang masih dapat digunakan sebagai kawasan permukiman. Berikut adalah lahan terbuka di Kawasan Pinggiran Kota Semarang yang saaat ini masih memungkinkan utuk dijadikan kawasan permukiman. Lahan yang dimaksudkan saat ini berfungsi sebagai Kebun Buah-Buahan, Pembibitan, Lahan Gundul Campuran, Lahan Hutan Hijau, Tanaman Semusim dan Lahan Rumput, yang luasnya adalah 1306,4 ha.

Tabel 4. Arahan Lokasi Permukiman dan Penggunaan Lahan Tahun 2016

\begin{tabular}{|c|c|c|c|c|}
\hline \multirow[b]{2}{*}{ Kecamatan } & \multirow[b]{2}{*}{ RTRW } & \multicolumn{3}{|c|}{ Penggunaan Lahan Tahun 2016} \\
\hline & & $\begin{array}{l}\text { Permukiman } \\
\text { (ha) }\end{array}$ & $\begin{array}{l}\text { Bukan Permukiman } \\
\text { (ha) }\end{array}$ & $\begin{array}{l}\text { Lahan Terbuka } \\
\text { (ha) }\end{array}$ \\
\hline Ngaliyan & Permukiman & 26,0 & 49,0 & 192,0 \\
\hline Mijen & Permukiman & 86,5 & 57,9 & 306,5 \\
\hline Tugu & Permukiman & 0,4 & 56,4 & 29,7 \\
\hline Semarang Barat & Permukiman & 26,3 & 214,9 & 74,9 \\
\hline Semarang Utara & Permukiman & 10,3 & 10,1 & 10,2 \\
\hline
\end{tabular}




\begin{tabular}{|c|c|c|c|c|}
\hline \multirow[b]{2}{*}{ Kecamatan } & \multirow[b]{2}{*}{ RTRW } & \multicolumn{3}{|c|}{ 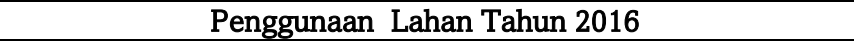 } \\
\hline & & $\begin{array}{l}\text { Permukiman } \\
\text { (ha) }\end{array}$ & $\begin{array}{l}\text { Bukan Permukiman } \\
\text { (ha) }\end{array}$ & $\begin{array}{l}\text { Lahan Terbuka } \\
\text { (ha) }\end{array}$ \\
\hline Genuk & Permukiman & 54,9 & 103,4 & 204,6 \\
\hline Pedurungan & Permukiman & 1,8 & 71,2 & 59,7 \\
\hline Tembalang & Permukiman & 10,5 & 88,4 & 45,7 \\
\hline Banyumanik & Permukiman & 4,4 & 209,5 & 205,5 \\
\hline Gunung Pati & Permukiman & 1,0 & 75,7 & 177,4 \\
\hline Total (ha) & 2465,0 & 222,1 & 936,6 & 1306,4 \\
\hline
\end{tabular}

Sumber : Hasil Analisis, 2016

\section{KESIMPULAN}

Perkembangan permukiman di Kota Semarang selama kurun waktu tahun 2006-2016 menyebar secara horisontal kearah pinggiran. Terjadi di 10 Kecamatan mencakup 114 kelurahan. Faktor yang berpengaruh terhadap perkembangan permukiman dapat diidentifikasi berdasarkan keterkaitan antara pertambahan luas permukiman dengan jarak dari pusat kota, (Yang, Xu, \& Long . 2016) kemudahan aksesibilitas ke pusat-pusat sarana permukiman, faktor bentuk karakteristik fisik, faktor ketersediaan fasilitas, faktor lingkungan sosial, demografi, serta faktor karakter dari lokasi dan tipikal permukiman (Golledge, R. G., \& Stimson, 1987)

Pekerjaan utama penduduk yang bertempat tinggal pada kawasan perkembangan bekerja sebagai buruh (Industri /Tani/Bangunan) dengan pendapatan rata - rata Rp 2.000.000 - Rp 3.500.000 / bulan. Tingkat pendidikan $\leq$ SD. Kondisi ini sesuai dengan matapencaharian mereka yang bekerja sebagai buruh. Kelengkapan sarana merupakan faktor yang paling berpengaruh terhadap perkembangan permukiman. Ada keterkaitan antara luas perkembangan permukiman dengan kelengkapan sarana permukiman. Semakin lengkap sarana semakin tinggi tingkat perkembangan permukimannya. Jarak dari pusat kota tidak berpengaruh terhadap luas perkembangan permukiman. Keberadaan kawasan rawan bencana menjadi faktor yang dipertimbangan dalam memilih lokasi permukiman. Permukiman cenderung berkembang teratur dengan pola yang seragam. Permukiman dengan karakter semacam ini merupakan indikasi hasil pembangunan yang dilakukan oleh pihak pengembang/ developer.

Hasil penelitian menunjukkan bahwa perkembangan permukiman juga terjadi di lokasi yang tidak sesuai dengan peruntukannya dan/atau arahan rencana tata ruang. Perkembangan permukiman yang terjadi pada lokasi rawan bencana akan membahayakan penduduk terutama pada lokasi terjadinya bahaya tanah longsor, banjir. Jika kondisi ini tidak segera mendapat perhatian dari pemerintah dikawatirkan perkembangan kota menyebar tanpa arah sehinga pola pergerakan penduduk tidak efisien karena akan menimbulkan kemacetan pada lokasi pusat kota dan/atau lokasi fasilitas perkotaan.. Pembatasan perkembangan permukiman dilakukan untuk mengendalikan perkembangan permukiman, dapat dilakukan dengan melarang pendirian bangunan permukiman pada lokasi yang tidak sesuai peruntukannya dan penertiban ijin bangunan, selanjutnya pemerintah perlu menindaklanjuti dengan pemberian informasi kepada masyarakat mengenai lokasi yang masih memungkinkan untuk dikembangkan sebagai kawasan permukiman. 


\section{DAFTAR PUSTAKA}

Ali, M. (2012). Kajian Dampak Perubahan Tutupan Lahan Terhadap Kejadian Banjir pada Lanskap DAS Ciliwung Hilir dengan Pendekatan Sistem Dinamik. Ipb. Institut Pertanian Bogor.

Bagheri, B., \& Tousi, S. N. (2017). An explanation of urban sprawl phenomenon in Shiraz Metropolitan Area (SMA). Cities, (September), 1-20. https://doi.org/10.1016/j.cities.2017.10.011

Bintarto. (1979). Metode Analisa Geografi. Jakarta: LP3ES.

Bourne, L. S. (1982). Internal Structure of the City. New York: Oxford University Press.

Branch, C. ; M. (1995). Perencanaan Kota Komperhensif : Pengantar dan Penjelasan. Yogyakarta: Gadjah Mada University Press.

Brueckner, J. K., \& Helsley, R. W. (2011). Sprawl and blight. Journal of Urban Economics, 69(2), 205-213. https://doi.org/10.1016/j.jue.2010.09.003

Budihardjo, E. (1991). Arsitektur dan Kota di Indonesia. Bandung: Alumni.

Chapin, F. stuart, \& Keiser, E. (1979). Urban Landuse Planning. United States America: The Board of Trustees of The University.

Cheng, H., Liu, Y., He, S., \& Shaw, D. (2017). From development zones to edge urban areas in China: A case study of Nansha, Guangzhou City. Cities, 71(December 2016), 110-122. https://doi.org/10.1016/j.cities.2017.07.015

Cheng, J. I. M. (2003). Urban growth pattern modelling : a case study of Wuhan city , PR China Urban growth pattern modeling : a case study of Wuhan city , PR China, 62(August), 199-217.

Daldjoeni. (1987). Geografi Kota dan Desa. Bandung: Alumni.

de la Luz Hernández-Flores, M., Otazo-Sánchez, E. M., Galeana-Pizaña, M., Roldán-Cruz, E. I., Razo-Zárate, R., González-Ramírez, C. A., ... Gordillo-Martínez, A. J. (2017). Urban driving forces and megacity expansion threats. Study case in the Mexico City periphery. Habitat International, 64, 109-122. https://doi.org/10.1016/j.habitatint.2017.04.004

Ding, C. (2009). Policy and planning challenges to promote efficient urban spatial development during the emerging rapid transformation in China. Sustainability, 1(3), 384-408. https://doi.org/10.3390/su1030384

Direktorat Jenderal Cipta Karya., \& Ikatan Ahli Perencanaan. (1998). Kamus Tata Ruang (edisi 1). Indonesia: Direktorat Jenderal Cipta Karya, Departemen Pekerjaan Umum bekerjasama dengan Ikatan Ahli Perencanaan Indonesia.

Doxiadis, C. A. . A. (1968). Introduction To The Science Of Human Settlements-Ekistics. London: Hutchinson of London.

Geneletti, D., La Rosa, D., Spyra, M., \& Cortinovis, C. (2017). A review of approaches and challenges for sustainable planning in urban peripheries. Landscape and Urban Planning, 165, 231-243. https://doi.org/10.1016/j.landurbplan.2017.01.013

Glaeser, Edward, L., Matthew, E., \& Kahn. (2003). Sprawl and Urban Growth (IV). Massachusetts: Harvard University.

Golledge, R. G., \& Stimson, R. (1987). Analitycal Behavioral Geography. Routledge.

Hagget, P. (1985). Geography: A Modern Synthesis. London: Harper and Row Publisher.

Jat, M. K., Choudhary, M., \& Saxena, A. (2017). Urban growth assessment and prediction using RS, GIS and SLEUTH model for a heterogeneous urban fringe. The Egyptian Journal of Remote Sensing and Space Science. https://doi.org/10.1016/j.ejrs.2017.02.002

Kostof, S. (1991). The City Shaped: Urban Patterns and Meanings Through History. Canada: Little Brown and Company.

Leaf, M. (2002). A tale of two villages: Globalization and peri-urban change in China and Vietnam. Cities, 19(1), 23-31. https://doi.org/10.1016/S0264-2751(01)00043-9

$\mathrm{Ma}, \mathrm{Y} .$, \& Xu, R. (2010). Remote sensing monitoring and driving force analysis of urban expansion in Guangzhou City, China. Habitat International, 34(2), 228-235. https://doi.org/10.1016/j.habitatint.2009.09.007

Oetomo, B. . dan K. (1998). Improving Urban Land Management In Indonesia: Urban Land Management: Improving Policies and Practicies In Developing Countries of Asia. New Delhi: Oxford \& IBH.

Pacione, M. (1984). Rural Geography. London: Harper and Row Publisher.

Pacione, M. (2005). Urban Geography: a Global Perspective (2nd Edition). London: Routledge.

Pemerintah. Keputusan Menteri Permukiman dan Prasarana Wilayah No. 534/KPTS/M/2001 tentang Standar Pelayanan Minimal untuk Permukiman (2001). Indonesia. 
Pemerintah. Undang-Undang No.26 Tahun 2007 tentang Penataan Ruang, Pub. L. No. 26, 107 (2007). Indonesia. Pigawati, B. dan I. R. (2011). Penggunaan Citra Satelit Untuk Kajian Perkembangan Kawasan Permukiman Di Kota Semarang, 25(2), 140-151.

Riddell, R. (2004). Sustainable Urban Planning Tipping The Balance. Willey.

Rodinelli, D. A., \& Ruddle, K. (1978). Urbanization and Rural Development: A Spatial Policy for Equitable Growth. New York: Preager Publisher. New York: Preager Publisher.

Rudiarto, I., Handayani, W., \& Pigawati, B. (2013). Zona Peri-Urban Semarang Metropolitan : Perkembangan. Tata Loka, 15(2), 116-128.

Solé-Ollé, Albert, \& Rico, M. H. (2010). Does Urban Sprawl Increase The Cost of Providing Local Public Services? Evidence from Spanish Municipalities. Urban Studies, 47(7), 1513-1540.

Soyinka, O., \& Siu, K. W. M. (2017). Investigating Informal Settlement and Infrastructure Adequacy for Future Resilient Urban Center in Hong Kong, SAR. Procedia Engineering, 198(September 2016), 84-98. https://doi.org/10.1016/j.proeng.2017.07.075

Spencer, M. (1979). Foundation of Modern Sociology. New Jersey: Prantice Hall Inc., Englewood Clieffs.

Sumaatmadja, N. (1989). Studi Lingkungan Hidup. Bandung: Alumni.

Tian, L., Liang, Y., \& Zhang, B. (2017). Measuring residential and industrial land use mix in the peri-urban areas of China. Land Use Policy, 69(July), 427-438. https://doi.org/10.1016/j.landusepol.2017.09.036

Wang, M., Krstikj, A., \& Koura, H. (2017). Effects of urban planning on urban expansion control in Yinchuan City , Western China. Habitat International, 64, 85-97. https://doi.org/10.1016/j.habitatint.2017.04.008

Warsono, A., Soetomo, S., \& Wahyono, H. (2012). Perkembangan Pemukiman Pinggiran Kota pada Koridor Jalan Kaliurang, Kabupaten Sleman. Jurnal Tata Kota Dan Daerah, 1(1), 19-23.

Weng, Q. (2010). Remote Sensing and GIS Integration: Theories, Methods, and Applications. New York: McGraw-Hill Company.

Widodo, B., Lupyanto, R., Sulistiono, B., Harjito, D. A., Hamidin, J., Hapsari, E., ... Ellinda, C. (2015). Analysis of Environmental Carrying Capacity for the Development of Sustainable Settlement in Yogyakarta Urban Area. Procedia Environmental Sciences, 28(SustaiN 2014), 519-527. https://doi.org/10.1016/j.proenv.2015.07.062

Wulangsari, A. (2014). Tipologi Segregasi Permukiman berdasarkan Faktor dan Pola Permukiman di Solo Baru , Sukoharjo, 10(4), 387-399.

Yang, R., Xu, Q., \& Long, H. (2016). Spatial distribution characteristics and optimized reconstruction analysis of China's rural settlements during the process of rapid urbanization. Journal of Rural Studies, 47, 413-424. https://doi.org/10.1016/j.jrurstud.2016.05.013

Yeh, A. G.-O. (1999). Urban Spatial Structure in a Transitional Economy. Journal of the American Planning Association, 65(4), 377-394. https://doi.org/10.1080/01944369908976069

Yunus, H. S. (2008). Dinamika Wilayah Peri Urban. Yogyakarta: Pustaka Pelajar.

Zee, D. Van Der. (1979). Human Geography of Rural Settlement and Population. Enchesde: ITC. 